\title{
Pengaruh Iklim Komunikasi Organisasi terhadap Motivasi Kerja Karyawan Telunjuk.com
}

\author{
Evan Septian Handra, Yugih Setyanto \\ evan.915170002@stu.untar.ac.id,yugihs@fikom.untar.ac.id
}

Fakultas Ilmu Komunikasi Universitas Tarumanagara

\begin{abstract}
The digital industry in Indonesia is growing quite rapidly, one of which is marked by the existence of many online shopping platforms. Telunjuk.com is a company that works and serves in the digital-based industry. The purpose of this study was to determine and measure the influence of organizational communication climate on employee motivation at Telunjuk.com. The population in this study has a total of 31 people, with the same number of samples, namely 31 people. This study adapted a total sample or census data collection technique and was calculated using a Likert scale. The data collection techniques in this study made use of a questionnaire and literature study. The validity test in this study uses the validity test and reliability test. The data processing method used is the T test, simple linear regression test, correlation coefficient and determination coefficient. The results showed that: (1) There is a significant influence between organizational communication climate on Telunjuk.com employee motivation, (2) The correlation test results show the Pearson correlation value which shows a very strong relationship between variables, (4) organizational communication climate 64, 1\% affects Telunjuk.com employee's work motivation.
\end{abstract}

Keywords: communication climate, organizational communication, work motivation

\begin{abstract}
Abstrak
Industri digital di Indonesia berkembang cukup pesat, salah satunya ditandai dengan adanya banyak platform belanja online. Telunjuk.com merupakan perusahaan yang melayani dalam ruang lingkup industri berbasis digital. Tujuan penelitian ini adalah untuk mengetahui serta mengukur pengaruh iklim komunikasi organisasi terhadap motivasi kerja karyawan di Telunjuk.com. Populasi dalam penelitian ini sejumlah 31 orang, dengan jumlah sampel yang sama, yaitu 31 orang. Penelitian ini mengadaptasi teknik pengumpulan data sampel total atau sensus dan dihitung dengan skala Likert. Teknik pengumpulan data dalam penelitian ini memanfaatkan angket kuesioner dan studi kepustakaan. Uji keabsahan dalam penelitian ini menggunakan uji validitas dan uji reliabilitas. Metode pengolahan data yang digunakan adalah uji $\mathrm{T}$, uji analisa regresi linear sederhana, analisa koefisien korelasi dan analisa koefisien determinasi. Penelitian menemukan bahwa: (1) iklim komunikasi organisasi berpengaruh secara signifikan terhadap motivasi kerja karyawan, (2) terdapat hubungan yang sangat kuat antara iklim komunikasi organisasi dan motivasi kerja karyawan, (3) iklim komunikasi organisasi $64,1 \%$ berpengaruh terhadap motivasi kerja karyawan.
\end{abstract}

Kata Kunci: iklim komunikasi, komunikasi organisasi, motivasi kerja

\section{Pendahuluan}

Manusia pada dasar dan hakikatnya adalah diciptakan sebagai mahluk sosial yang erat kaitannya dengan proses komunikasi. Proses komunikasi yang dilakukan manusia pun beragam dan memiliki banyak bentuk seperti verbal, non-verbal, 
antarpribadi, kelompok kecil, organisasi, komunikasi massa, hingga berskala global. Kemampuan manusia dalam berkomunikasi juga merupakan suatu esensi dalam kegiatan sehari-hari. Begitu pula di dalam suatu perusahaan atau organisasi, tiap anggotanya harus dapat berkomunikasi dengan baik satu sama lain.

Komunikasi dalam sebuah organisasi merupakan suatu komponen penyusun suatu konsep iklim komunikasi organisasi. Ruben dan Steward dalam bukunya yang berjudul Komunikasi dan perilaku manusia, mengemukakan bahwa di tempat iklim komunikasi yang suportif berkembang, yang mana juga dapat mempengaruhi tingkat kepuasan kerja menjadi tinggi, maka produktivitas juga dapat ditingkatkan. Iklim komunikasi menjadi suatu unsur yang penting dalam meningkatkan produktivitas. Hal ini dapat terjadi karena iklim komunikasi dapat memengaruhi keputusan, pedoman hidup, dan cara berperilaku dari anggota organisasi (Melia \& Tamburian, 2018: 442).

Selain iklim komunikasi yang efektif untuk memenuhi kinerja, karyawan juga memerlukan motivasi kerja yang memadai guna menunjang kinerja. Menurut R. Wayne Pace, motivasi mendefinisikan alasan individu untuk senantiasa mencurahkan tenaganya bagi suatu pekerjaan (Pace, 2018: 113). Motivasi memiliki peran utama dalam setiap diri individu terhadap kinerja yang dikehendakinya untuk diberikannya kepada perusahaan atau organisasi. Semakin besar energi yang dicurahkan untuk bekerja, individu tersebut diasumsikan oleh lingkungannya sebagai pribadi yang termotivasi.

Dari penjabaran tersebut, motivasi sangat erat kaitannya dengan kinerja individu dalam organisasi. Menurut Ernika, memberikan motivasi dengan mendorong karyawan baik dari segi fisik, mental,maupun rohani, dapat meningkatkan kinerja sehingga mencapai hasil yang diinginkan (Ernika, 2016: 88). Panuju dan Narena mengemukakan bahwa iklim komunikasi organisasi dan motivasi kerja merupakan beberapa indikator yang dapat digunakan untuk mengukur kualitas komunikasi yang terjadi dalam sebuah organisasi (Panuju \& Narena, 2019: 34-35). Tentunya indikator-indikator tersebut berpengaruh terhadap kelangsungan kerja serta kepentingan organisasi, termasuk di Telunjuk.com yang merupakan salah satu perusahaan rintisan yang bergerak di bidang e-commerce hub di Indonesia (Linkedin, 2020).

Permasalahan yang menjadi dasar topik pembahasan dalam penelitian ini adalah apakah terdapat pengaruh iklim komunikasi organisasi terhadap motivasi kerja karyawan di Telunjuk.com? Hipotesis awal dalam penelitian ini adalah tidak ada pengaruh iklim komunikasi organisasi terhadap motivasi kerja karyawan Telunjuk.com, dan terdapat pengaruh iklim komunikasi organisasi terhadap motivasi kerja karyawan Telunjuk.com.

\section{Metode Penelitian}

Pendekatan penelitian yang digunakan pada penelitian ini mengadaptasi survei sebagai pedoman pendekatan dalam penelitian. Pendekatan kuantitatif didefinisikan sebagai penelitian yang berlandaskan pada pegangan positivisme, yang mana untuk meneliti dari suatu populas dan sampel, melibatkan instumen penelitian dalam pengumpulan data, analisis datamenggunakan statistika dan prinsip kuantitatif, dengan tujuan mengujicobakan hipotesis yang telah ditetapkan (Sugiyono, 2019: 1617). 
Teknik pengumpulan data yang penulis gunakan adalah menggunakan angket kuesioner dan studi pustaka sebagai instrumen penelitian. Populasi dalam penelitian ini adalah seluruh karyawan Telunjuk.com yang berjumlah 31 orang, dengan sampel berjumlah 31 orang karena jumlah populasi kurang dari 100 orang. Skala pengukuran yang digunakan adalah skala likert 4 poin. Menurut Sugiyono (dalam Hertanto, 2017: 2), skala likert digunakan untuk mengukur pendapat, persepsi, dan sikap seseorang atau sekelompok individu terkait dengan fenomena sosial. Poin dalam skala likert 4 poin bernilai Sangat Setuju (4), Setuju (3), Tidak Setuju (2), Sangat Tidak Setuju (1).

Gambar 1. Kerangka Pemikiran

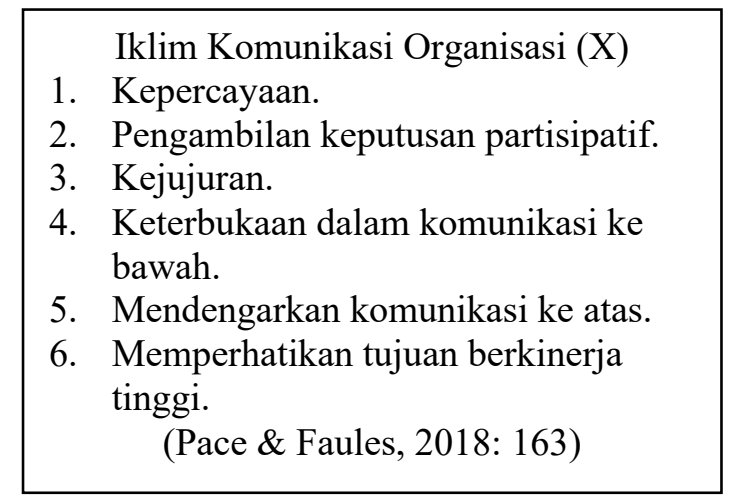

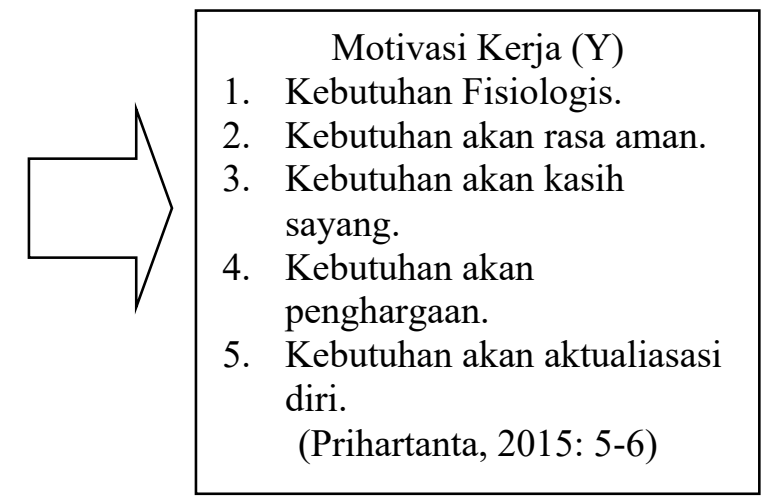

Sumber: Dokumentasi Pribadi

Dalam melakukan analisis data, penulis menggunakan perangkat lunak berupa program aplikasi SPSS versi 25. Adapun uji yang dilakukan dalam penelitian ini antara lain:

\section{Uji Validitas dan Reliabilitas}

Uji validitas dan reliabilitas dilakukan untuk membuktikan keabsahan suatu data penelitian. Uji validitas menggunakan metode Corrected Item Total Correlation dan uji reliabilitas menggunakan metode Cronbach's Alpha. Dari pengujian validitas, ditemukan bahwa indikator dengan kode X2, X4, Y2, Y3, Y4, Y9, Y12, dan Y13 dinyatakan tidak valid sehingga tidak diikutsertakan pada uji-uji berikutnya. Setelah pengujian ulang kembali, seluruh data dinyatakan valid dan reliabel.

\section{Uji Normalitas}

Uji normalitas adalah sebuah uji untuk membuktikan tingkat kenormalan distribusi data sehingga dapat digunakan dalam operasi statistik parametris (Widhiarso, 2017: 1).

\section{Uji T}

Uji T dilakukan untuk mengetahui apakah hipotesis nol diterima atau ditolak. Apabila nilai Sig. lebih besar dari taraf signifikasi 0,05 maka hipotesis nol diterima. Namun apabila nilai Sig. lebih kecil dari taraf signifikasi 0,05 maka hipotesis nol dinyatakan ditolak (Sujarweni, 2015).

\section{Uji Analisis Regresi}

Uji analisis regresi mengeksplorasi signifikansi hubungan antar variabel yang diujikan dalam penelitian ini, yaitu variabel bebas atau independen dan variabel 
terikat atau dependen. Dengan uji ini, dapat diketahui apakah variabel independen berpengaruh secara signifikan terhadap variabel dependen (Yuliara, 2016: 6).

\section{Uji Koefisien Korelasi}

Uji koefisien korelasi adalah suatu statistik infarensi yang dioperasikan untuk menguji apakah dua variabel memiliki hubungan atau tidak (Sujarweni, 2015: 126). Hasil korelasi disajikan dalam bentuk tingkat hubungan antara sangat lemah hingga korelasi sempurna.

\section{Uji Koefisien Determinasi}

Uji koefisien determinasi menghasilkan suatu persentase pengaruh variabel bebas ata independen terhadap variabel terikat atau dependen (Sujarweni, 2015: 149). Hasil koefisien determinasi disajikan dalam bentuk persentase.

\section{Hasil Temuan dan Diskusi}

Tabel 1. Uji Normalitas One Sample Kologorov Smirnov

\begin{tabular}{llr}
\hline & & Unstandardized Residual \\
\hline $\mathrm{N}$ & & 31 \\
\hline \multirow{2}{*}{ Normal Parameters } & Mean &, 0000000 \\
\cline { 2 - 3 } & Std. Deviation & 3,23067696 \\
\hline Most & Extreme &, 133 \\
Differences & Absolute &, 105 \\
\cline { 2 - 3 } & Positive &,- 133 \\
\cline { 2 - 3 } & Negative &, 133 \\
\hline Test Statistic & &, 175 \\
\hline Asymp. Sig. (2-tailed) & & \\
\hline
\end{tabular}

Sumber: Pengolahan Data Peneliti

Tabel 1 menunjukkan bahwa nilai Asmp. Sig. $=0,175$ lebih besar dari taraf siginifikasi 0,05 . Maka dapat dinyatakan bahwa data penelitian telah berdistribusi normal dan siap diujikan dalam statistik parametris.

Tabel 2. Uji Regresi Linear Coefficients

\begin{tabular}{|c|c|c|c|c|c|}
\hline \multirow[t]{2}{*}{ Model } & \multicolumn{2}{|c|}{$\begin{array}{l}\text { Unstandardized } \\
\text { Coefficients }\end{array}$} & \multirow{2}{*}{$\begin{array}{c}\text { Standardized } \\
\text { Coefficients } \\
\text { Beta }\end{array}$} & \multirow[t]{2}{*}{$\mathrm{t}$} & \multirow[t]{2}{*}{ Sig } \\
\hline & $\mathrm{B}$ & Std. Error & & & \\
\hline (Constant) & 3,322 & 5,833 & & 570 &, 573 \\
\hline $\begin{array}{l}\text { Iklim Komunikasi } \\
\text { Organisasi }\end{array}$ &, 831 & ,115 & ,801 & 7,199 & ,000 \\
\hline
\end{tabular}

Sumber: Pengolahan Data Peneliti

$$
\begin{aligned}
& Y=a+b X \\
& Y=3,322+0,831 X
\end{aligned}
$$

Tabel 2 menunjukkan sebagai indikator Uji T, dapat dilihat bahwa nilai Sig.= $0,000<0,05$ menyatakan bahwa hipotesis nol ditolak, sehingga ditemukan bahwa terdapat pengaruh antara iklim komunikasi organisasi yang merupakan variabel bebas terhadap motivasi kerja yang merupakan variabel terikat. Persamaan regresi menunjukkan bahwa apabila variabel $(\mathrm{X})$ bernilai nol, maka nilai variabel (Y) adalah 
Evan Septian Handra, Yugih Setyanto: Pengaruh Iklim Komunikasi Organisasi terhadap Motivasi Kerja Karyawan Telunjuk.com

3,322. Namun, apabila variabel $(\mathrm{X})$ mengalami peningkatan satuan, maka variabel $\mathrm{Y}$ akan mengalami peningkatan sebesar 0,831 .

Tabel 3. Uji Regresi Linear Model Summary

\begin{tabular}{ccccc}
\hline Model & $\mathrm{R}$ & R Square & $\begin{array}{c}\text { Adjusted R } \\
\text { Square }\end{array}$ & $\begin{array}{c}\text { Std. Error of } \\
\text { the Estimate }\end{array}$ \\
\hline 1 &, 801 &, 641 &, 629 & 3,286 \\
\hline
\end{tabular}

Sumber: Pengolahan Data Peneliti

Tabel 3 menunjukkan bahwa nilai $\mathrm{R}$ atau korelasi antar variabel sebesar 0,801. Nilai tersebut dikategorikan sebagai hubungan yang sangat kuat. Dapat dikatakan bahwa hubungan antara iklim komunikasi organisasi dan motivasi kerja karyawan di Telunjuk.com sangat kuat. Nilai $R$ Square merupakan pengkudratan dari nilai $R$, yang menentukan nilai koefisien determinasi. Temuan menunjukkan bahwa nilai $R$ Square sebesar 0,641 . Hal tersebut menunjukkan bahwa iklim komunikasi organisasi berpengaruh sebesar $64,1 \%$ terhadap motivasi kerja karyawan Telunjuk.com.

Berdasarkan pembuktian hipotesis melalui uji $\mathrm{T}$ yang dilakukan pada data penelitian, diambil kesimpulan bahwaiklim komunikasi organisasi berpengaruh secara signifikan terhadap mitivasi kerja karyawan Telunjuk.com. Hal ini berarti, secara umum, iklim organisasi yang diterapkan di Telunjuk.com berpengaruh terhadap motivasi kerja karyawan. Iklim komunikasi yang terbuka, penuh dengan kepercayaan serta kejujuran menurut Pace dan Faules (2018: 163), secara langsung memenuhi dimensi-dimensi motivasi seperti kebutuhan fisiologis, rasa aman, kasih sayang, penghargaan, serta aktualisasi diri (Prihartanta, 2015: 5-6). Hasil uji hipotesis yang signifikan juga menandakan bahwa keadaan tersebut berlaku bagi seluruh populasi (Yuliara, 2016: 6).

Uji analisis regresi menunjukkan peramalan apabila variabel iklim komunikasi organisasi mengalami peningkatan, maka motivasi kerja juga akan ikut meningkat. Hasil analisis regresi tersebut ikut mendukung pembuktian hipotesis penelitian, bahwa iklim komunikasi organisasi berpengaruh secara signifikan terhadap motivasi kerja karyawan Telunjuk.com.

Dalam uji korelasi yang telah dilakukan terhadap data penelitian, telah diketahui intensitas pengaruh antara iklim komunikasi organisasi terhadap motivasi kerja karyawan Telunjuk.com menunjukkan indikator sangat kuat. Penulis menyimpulkan bahwa keeratan pengaruh antar variabel ini dapat ditelusuri pula dari hasil pengukuran tiap-tiap variabel dengan instrumen penelitian. Dengan terpenuhinya dimensi iklim komunikasi yang baik dan nyaman bagi karyawan, berpengaruh pada peningkatan motivasi karyawan secara langsung.

Dalam uji koefisien determinasi, dinyatakan bahwa 64,1\% motivasi kerja karyawan di Telunjuk.com dipengaruhi oleh iklim komunikasi organisasi. Hasil pengujian ini kembali mendukung pembuktian hipotesis yang telah dilakukan.kemunian untuk variabel lain yang tidak diteliti berpengaruh sebesar $35,9 \%$. Adanya pengaruh yang signifikan antara iklim komunikasi organisasi dengan motivasi kerja karyawan mendukung argumen bahwa manajemen perlu memperhatikan serta memelihara iklim komunikasi yang terjadi dalam lingkungan organisasi. Dapat dikatakan bahwa iklim komunikasi yang baik dan mendukung kedua belah pihak, tentunya berdampak bagi banyak instrumen dalam pekerjaan, salah satunya ialah motivasi kerja karyawa 


\section{Simpulan}

Penelitian ini menarik kesimpulan: (1) Iklim komunikasi organisasi berpengaruh secara signifikan terhadap motivasi kerja karyawan Telunjuk.com; (2) adanya hubungan sangat kuat antara iklim komunikasi organisasi terhadap motivasi kerja karyawan Telunjuk.com; (3) iklim komunikasi organisasi 64,1\% mempengaruhi motivasi kerja karyawan, sedangkan sisa 35,9\% dipengaruhi oleh faktor lain yang tidak diteliti dalam penelitian ini.

\section{Ucapan Terima Kasih}

Penulis menyadari bahwa penelitian ini dapat dilangsungkan oleh karena dukungan dari banyak pihak. Oleh karena itu, penulis mengucapkan terimakasih pada dosen pembimbing, Fakultas Ilmu Komunikasi Universitas Tarumanagara, Kak Nova dan para karyawan Telunjuk.com yang sudah bersedia memberikan tanggapannya dalam kuesioner dan membantu penulis dalam mengumpulkan data dalam penelitian ini.

\section{Daftar Pustaka}

Ernika, D. (2016). Pengaruh Komunikasi Organisasi Dan Motivasi Terhadap Kinerja Karyawan Pada PT. Inti Tractors Samarinda. EJournal Ilmu Komunikasi Universitas Mulawarman, 4(2), 87-101.

Hertanto, E. (2017). Perbedaan Skala Likert Lima Skala Dengan Modifikasi Skala Likert Empat Skala. Retrieved December 2, 2020, from Academia: https://www.academia.edu/34548201/PERBEDAAN_SKALA_LIKERT_LI MA_SKALA_DENGAN_MODIFIKASI_SKALA_LIKERT_EMPAT_SKA LA

Melia, H. D., \& Tamburian, H. D. (2018). Pengaruh Iklim Komunikasi Organisasi Terhadap Kinerja Pegawai. Koneksi, 2(2), 441-448.

Pace, R. W., \& Faules, D. F. (2018). Komunikasi Organisasi Strategi Meningkatkan Kinerja Perusahaan. Bandung: Remaja Rosdakarya.

Prihartanta, W. (2015). Teori-Teori Motivasi. Jurnal Adabiya, 1(83), 1-11.

Sugiyono. (2019). Metode Penelitian Kuantitatif Kualitatif dan R\&D(2nd ed.). Bandung: Alfabeta.

Sujarweni, V. W. (2015). SPSS Untuk Penelitian. Yogyakarta: Penerbit Pustaka Baru Press.

Telunjuk.com. (n.d.). Telunjuk.com - PT. Telunjuk Komputasi Indonesia. Retrieved October 27, 2020, from Linkedin: https://id.linkedin.com/company/telunjukcom

Widhiarso, W. (2020). Uji Normalitas. Repository Universitas Gadjah Mada

Yuliara, I. M. (2016). MODUL REGRESI LINIER SEDERHANA. Fakultas Matematika Dan Ilmu Pengetahuan Alam Universitas Udayana, 1-10. Retrieved March 16, 2020, from SIMDOS Universitas Udayana: https://simdos.unud.ac.id/uploads/file_pendidikan_1_dir/3218126438990fa07 71ddb555f70be42.pdf 